\title{
IMPACTS OF GLACIER-RELATED LANDSLIDES ON THE SETTLEMENT AT HOPAR, KARAKORAM HIMALAYA
}

\author{
by
}

\author{
K.I. MacDonald
}

(Department of Geography, University of Waterloo, Waterloo, Ontario N2L 3G1, Canada)

\section{ABSTRACT}

Slope instability and occasional devastating landslides are well-known hazards in high mountain areas. This paper describes and discusses an example of extensive and recurring damage associated with agricultural settlements around the lower reaches of the rapidly flowing Bualtar and Barpu Glaciers in northern Pakistan. These landslides occur over a zone about $20 \mathrm{~km}$ long in response to erosive processes at the ice-slope interface, and slowly descend $150-300 \mathrm{~m}$ from the edges of cultivation to the glacier margins. Damage is evident in the loss and/or abandonment of approximately $10 \mathrm{~km}^{2}$ of land, and in the destruction of dwellings and irrigation channels. The daily routine of local villagers is affected because alterations of both the slope and the ice surface destroy frequently used transport routes. Although the landslides have a history decades long, the landslide problem has more recently assumed heightened significance in relation to rapidly occurring economic and social change such as the introduction of wage labour and seasonal outmigration.

\section{INTRODUCTION}

Large destructive mass movements are characteristic problems of mountain lands, affecting communities and resource development throughout the world; usually, we hear of them when they cause singular disasters. Larger and widespread risks, however, are usually associated with numerous small-scale events and with ongoing patterns of slope instability arising from tectonic, climatic, or man-induced changes in the environment. All of these have played significant roles in the recurring problems of slope instability and destructive mass movements in the Upper Indus Basin of northern Pakistan.

Human settlement around and above the lower reaches of the Bualtar and Barpu Glaciers in the Karakoram Himalaya $\left(36^{\circ} 14^{\prime}\right.$ N., $74^{\circ} 46^{\prime}$ E.) (Fig. 1) has been subjected to stress associated partly with a series of intermittent landslides. Fluctuations of these glaciers have, in the recent past, resulted in the flooding and erosion of land and more significantly in the triggering of a series of large landslides along about $20 \mathrm{~km}$ of ice margin. These landslides occur on the steep glacier-facing slopes of lateral moraines and impinge upon irrigated agricultural land which is located on the more gently sloping side of the moraine at Hopar, and which reaches within $50 \mathrm{~m}$ of the ridge crest. Serious disruption to irrigation channels, deep fissures in fields, and the loss of approximately $10 \mathrm{~km}^{2}$ of crop and grazing land over a period of centuries, if not decades, has resulted from slumping of the steep face and associated recession of the crest down the gentle slope. Extensive damage to village land and associated structures continues today.

A field program was undertaken in the months of April through to September 1986, and in July and August of 1987, in order to map the affected areas, to document the material effects of landsliding upon slopes and land use, and to examine human response to these problems. Physical processes connecting glacier fluctuations and movement of the surrounding slopes have also been investigated. This paper describes the approach and discusses the extent of physical and economic damage in the Hopar valley.

\section{LOCATION}

Hopar, with approximately 4000 inhabitants, is composed of five distinct villages and their co-terminous lands. The villages, which constitute the highest permanent settlement in Nagyr district, are situated in a broad depression between the left lateral moraine of Bualtar Glacier to the east and steep rock walls to the west (Fig. 1). Cultivation is undertaken between 2500 and $3000 \mathrm{~m}$ a.s.1., and is dependent upon melt water derived from snowfall at higher elevations. Through a complex network of irrigation channels, water is delivered to the terraced fields on the valley slopes and the valley floor.

In the past, the subsistence economy relied primarily upon the husbandry of wheat, barley, potatoes, and apricots, and the rearing of sheep, goats, cattle, and yak. In recent years, however, the introduction of an external economy has altered patterns of employment and production. Increasingly, some of the men find it desirable to supplement their income by wage labour, which is available either locally

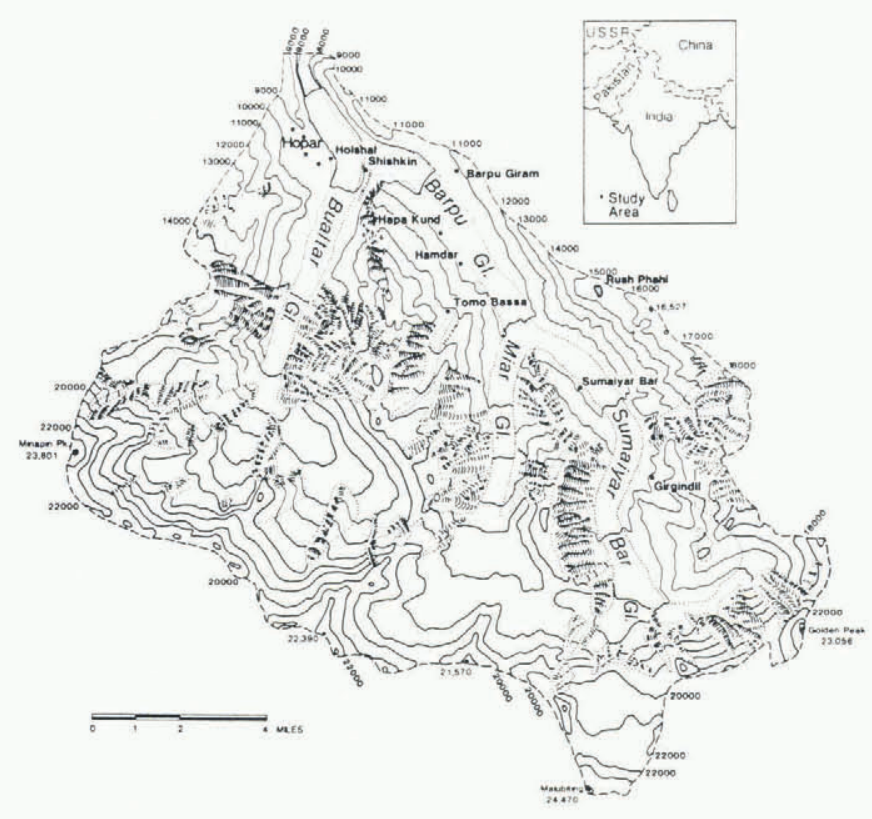

Fig. 1. Location of study area. 


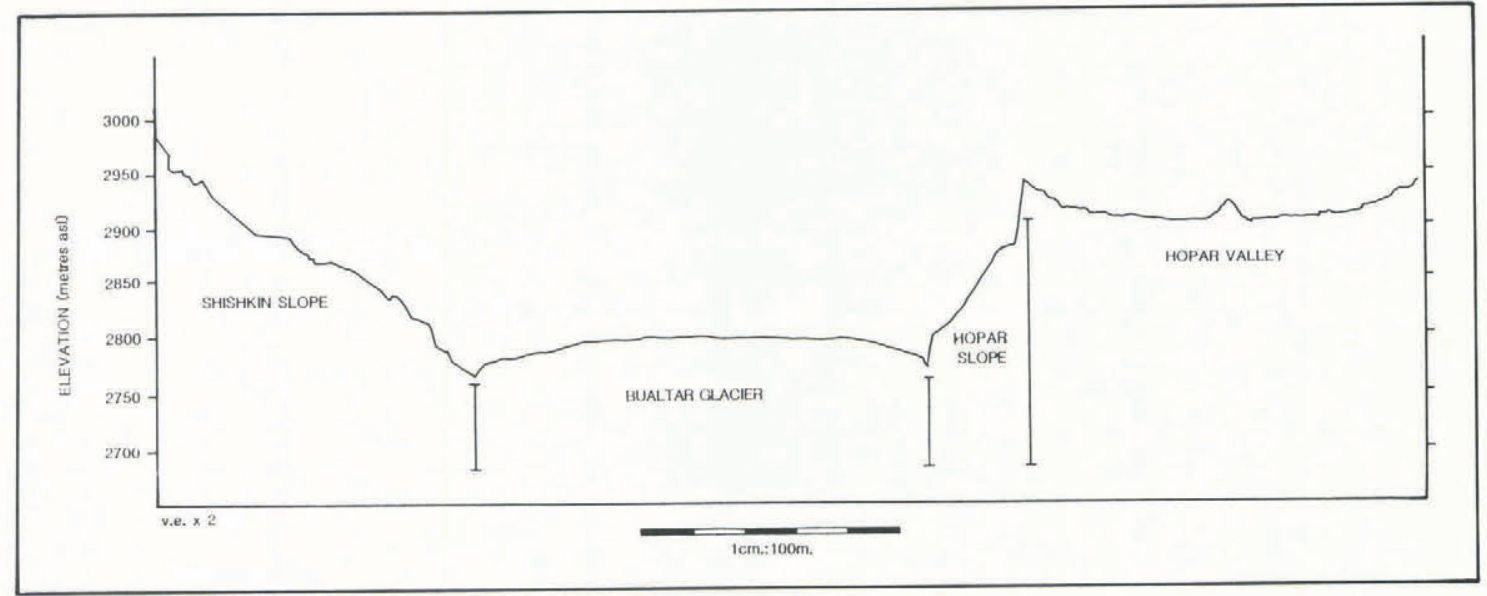

Fig. 2. Cross-section of surveyed areas of Hopar, Shishkin, and Bualtar Glacier, 1986.

(expedition porters) or outside the valley (army or factory workers). Services in Hopar are minimal; a precarious jeep track links the villages to a main transport route; transport is usually by foot or pack animal; and paths fan out from the villages and cross the glacier to areas of summer pasture or to the sources of wood and fuel.

\section{LANDSLIDES}

Landslides occur in poorly consolidated glacial, glacio-fluvial, glacio-lacustrine, and slope deposits and, although complex, most closely resemble what have been called earth-slumps (Varnes, 1978) or slump-earth-flow landslides (Jones and others, 1961). Very large slumps and countless smaller dry sand flows (Varnes, 1978) occur along both margins of Bualtar Glacier in Hopar, Shishkin, and Chinderdas. Figure 2 indicates the scale and general form of the steep moraine slopes at Hopar and Shishkin in relation to the Hopar valley and Bualtar Glacier. Detached blocks stand in high-angle $\left(>40^{\circ}\right)$ cliffs between 150 and $300 \mathrm{~m}$ high. Earth-slumps result in part from the behaviour of the rapidly flowing Bualtar Glacier.

\section{OBSERVED BEHAVIOUR OF BUALTAR GLACIER}

Using stake networks, surface velocities and ablation were measured. An approximate melt rate of $10-12 \mathrm{~m} \mathrm{a}^{-1}$ was indicated, while averaged surface velocities between May and September 1986 ranged from 0.33 to $1.10 \mathrm{~m} \mathrm{~d}^{-1}$, indicating annual movement of about $100 \mathrm{~m}$. The transverse velocity of Bualtar Glacier, however, is not convex down-glacier; ice within $100 \mathrm{~m}$ of the glacier margins is moving at the same rate as and in some cases faster than ice in the centre, and this results in the rapid removal of landslide debris from the base of marginal slopes.

At the end of July 1986, three large rock avalanches fell on to the glacier about $5 \mathrm{~km}$ up-stream of Hopar and covered $4-5 \mathrm{~km}^{2}$ of the surface, thus substantially modifying the ice-surface topography. Glacier movement was significantly increased following these events; from 13 to 31 May 1987, rates of movement averaged $7.59 \mathrm{~m} \mathrm{~d}^{-1}$ in the lower reaches and $3.11 \mathrm{~m} \mathrm{~d}^{-1}$ where the rockslides were deposited; in this zone, velocity dropped to an average of $2.12 \mathrm{~m} \mathrm{~d}^{-1}$ between 3 June and 4 July and to $0.62 \mathrm{~m} \mathrm{~d}^{-1}$ through to 18 August when measurements ceased. This rapid increase in velocity enhanced erosion processes at the ice margin and appears significantly to have accelerated the rate of slumping on the lower slopes (cf. Hewitt, 1988).

\section{OBSERVATIONS OF HOPAR SLOPE}

Initiation of failure behind the steep moraine crest begins with the development of incipient sub-vertical fissures parallel with the steep slopes and giving subarcuate to arcuate cracks in plan. Gradually, these fissures extend in both width and depth as large blocks slump and descend down the slip face (Fig. 3). Down-slope there is a vertical transition in form of the relatively intact blocks found at the top through various stages of break-up. At lower levels, entire areas of the steep face appear as series of superimposed slumps coalescing near the glacier margin. The distal toes of the deposits are continually cleared by rapid ice flow as debris is both incorporated subglacially and also transported in marginal melt-water streams. Movement of blocks down the face appears to be slow and intermittent, as no appreciable movement of developing

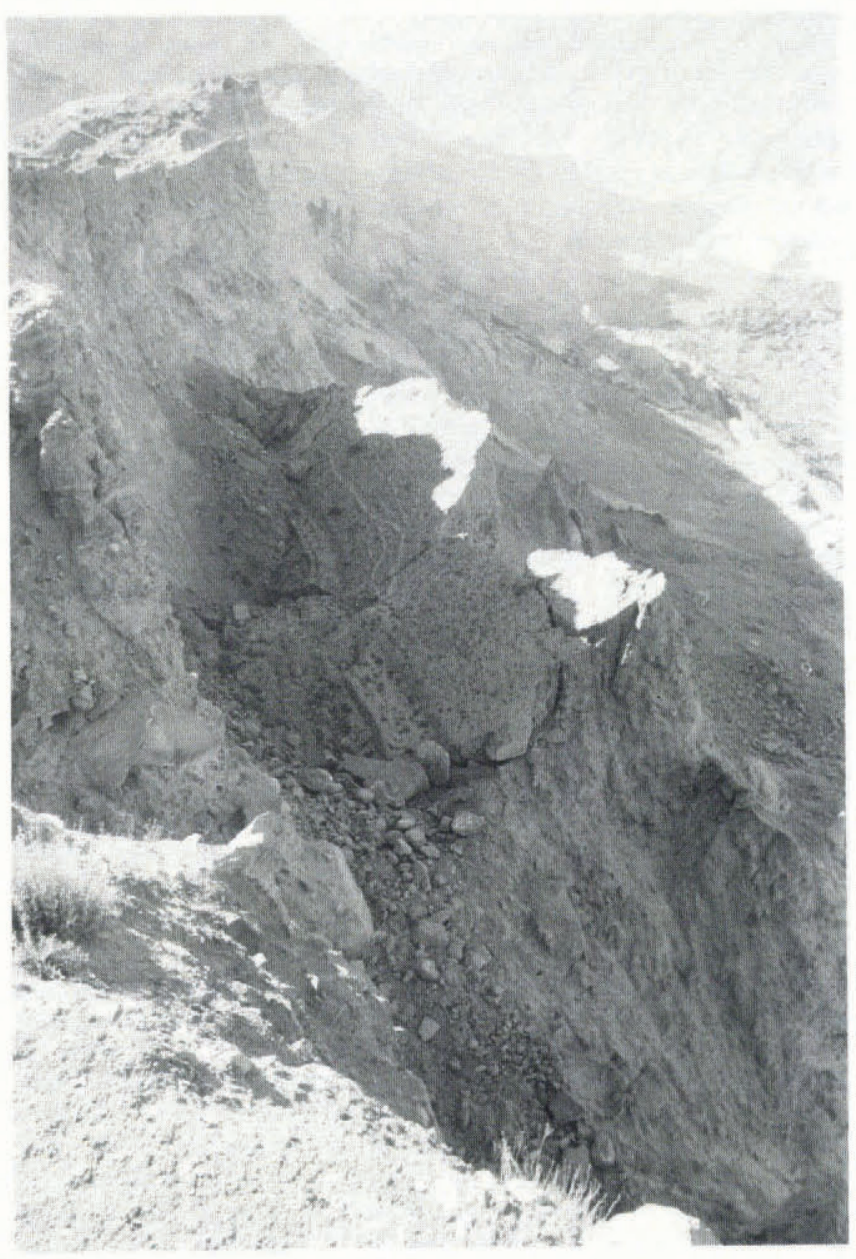

Fig. 3. Slump blocks on Hopar slope. Block in foreground, detached about 8 years ago, now sits $35 \mathrm{~m}$ down the face and has carried away the old jeep road. View from moraine crest down-glacier, showing Bualtar Glacier in upper right corner. 
slump blocks or degraded slump masses was detected during two consecutive years of observation. Local residents sugges that one particular slump block which now sits $35 \mathrm{~m}$ down the cliff face became detached in 1979 or 1980, indicating an average movement rate of about $4.5 \mathrm{~m} \mathrm{a}^{-1}$. From recorded measurements and the statements of local inhabitants, it is suggested that movement is periodic and is related to a number of factors including fluctuating therma conditions on the face and the rapid infusion of water down the cliff face during spring snow melt. The presence of at least two small springs surfacing about halfway down the exposed cliff face also suggests that the action of ground water reduces the shear strength of parts of the slope. Further, basal erosion through rapid flow at the iceslope interface and the thinning of Bualtar Glacier act to remove lateral support and increase shear stress at the base of the slope.

\section{IMPACT AND RESPONSE}

The hazard condition is of interest not only on account of its physical form, but also because of the proximity of settlement and cultivation. Eisbacher and Clague (1984), for example, made no mention of landslides occurring in lateral moraines in their discussion of glacier-related mass movements. Further, damage associated with glacier-related hazards generally occurs at elevations below the level of permanent ice, being caused by glacier advance, over-riding of pro-glacial areas, and glacial and fluvio-glacial deposition processes. In Hopar, however, land is lost from above the elevation of permanent ice and this is related to the erosive potential of the glacier. Most landslides are active along the margin of cultivation and develop between 250 and $400 \mathrm{~m}$ from the edge of settled areas. The pattern of damage and the response of valley inhabitants is associated with various phases of landsliding.

Fissures opening at the head of new slides and incipient slumping sever or damage irrigation channels, footpaths, terraced land, terrace walls, and in some cases dwellings on the gently sloping side of the moraine.
Continued movement of material down the cliff face reduces cultivated land areas, putting an end to intensive use. The repair or creation of new paths and irrigation channels is necessitated at lower elevations. Eventually, the surface becomes broken and travels so far down the cliff face that the useful productive capacity of the land is finally lost. The human response is typically one of minimal land use leading to abandonment. With the recession of the crest and the concomitant shrinkage of the cultivated area, land is either allocated to lower-valued uses or abandoned. The villagers leave a strip of land, essentially forming a buffer zone, between the cliff edge and the edge of the field which is used for grazing animals and the collection of shrubs (Artemisia sp.) for fuel. The width of this buffer zone is determined by the distance between the irrigation channels that run sub-parallel to the cliff edge. As one channel is destroyed, the margin of cultivation drops below a subsequent channel at a lower elevation. This land is now excluded from irrigation and eventually rendered useless by a major slide event.

Considering the processes discussed above, the extent of physical and economic damage in Hopar is evident. As average annual precipitation is less than $130 \mathrm{~mm}$ at elevations below $3500 \mathrm{~m}$ a.s.1., irrigation water is the mainstay of life. Thus, the most severe physical impact is the occasional disruption of water supply and the infrequent complete destruction of irrigation channels. Similar landslides to those described for Hopar led to the abandonment of the settlement at Shishkin, a large summer village at the right side of Bualtar Glacier (Fig. 1) within the last quarter century. According to local informants, Shishkin once consisted of 40-50 dwellings, with terraced fields in which irrigation water supported the cultivation of wheat, barley, potatoes, alfalfa, and apricots. A combination of the rapid thinning of Barpu Glacier (Fig. 1) in the last 20 years to levels below those at which melt water can be delivered by gravity to the fields, and the recurring slumping of the moraines have hindered efforts to reconstruct irrigation channels across the slope, effectively putting an end to farming (Fig. 4). The extent of physical damage in Shishkin is shown in Figure 5.

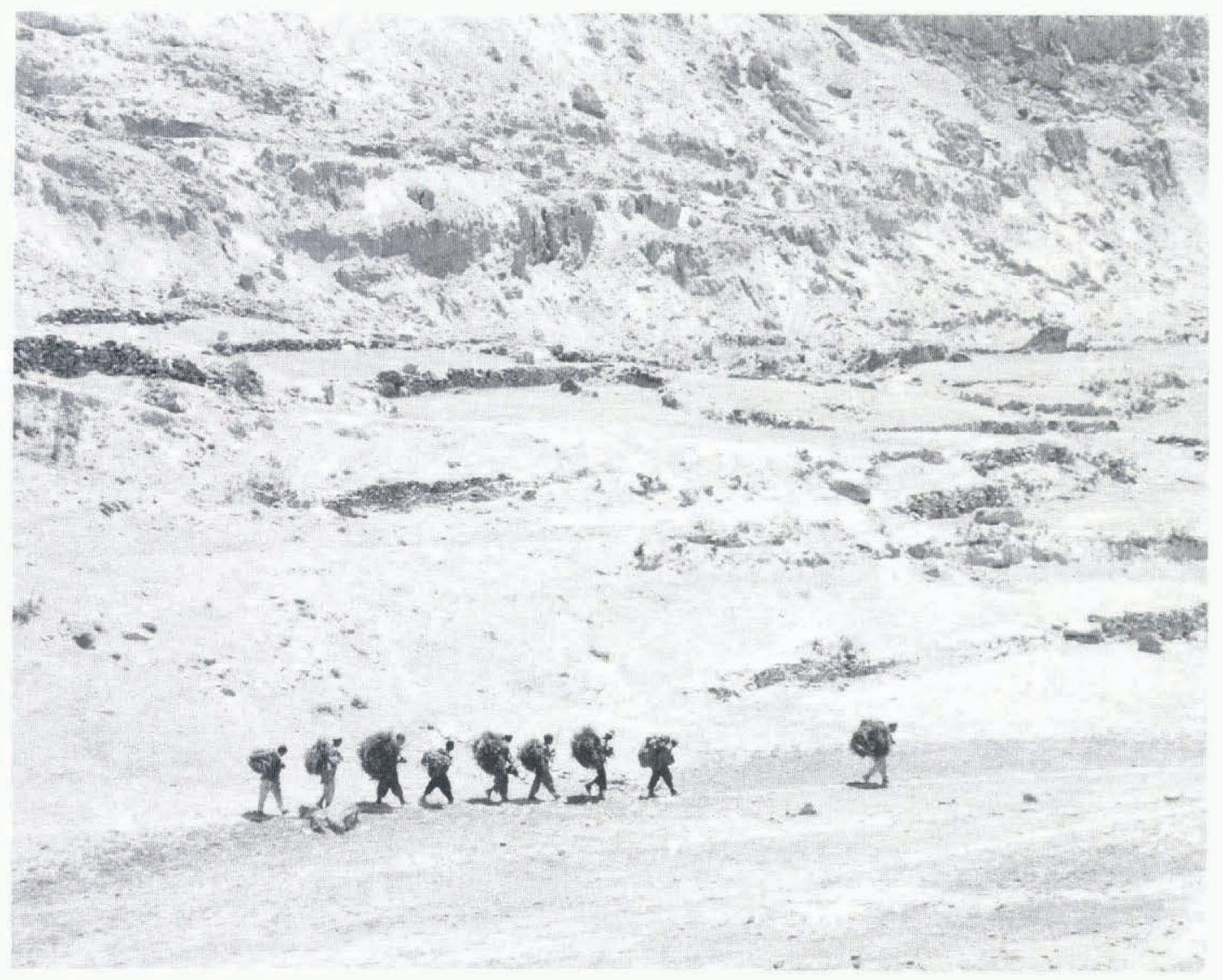

Fig. 4. Hopar villagers carrying firewood across fields of Shishkin. Note abandoned terraces, and slide scarps in upper half of photograph. 


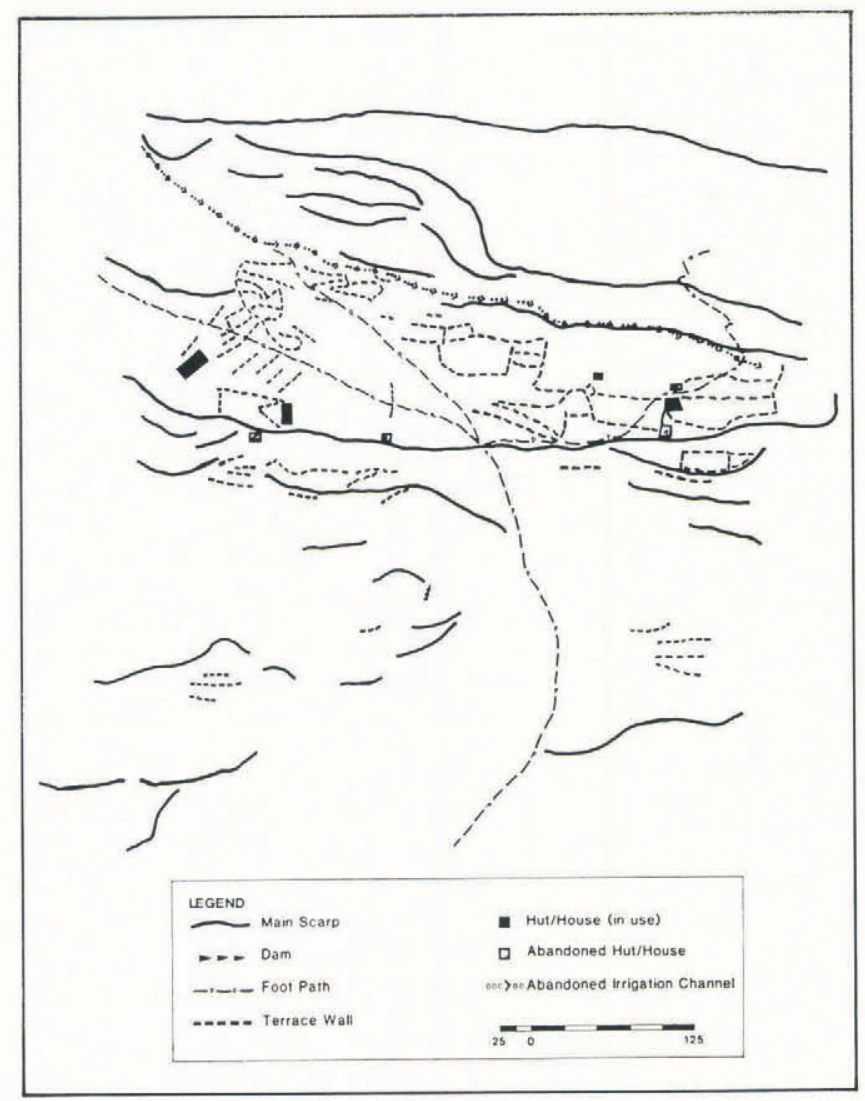

Fig. 5. Field map of position of major landslip scarps and land-use loss features at Shishkin.

Another major impact of these landslides is the interruption and destruction of transport routes. Small footpaths which are routed on top of, and descend, the Hopar cliff face, lead across Bualtar Glacier to areas of summer pasture and wood fuel. They are continually altered due to patterns of sliding. In addition, Hopar recently lost large sections of the original jeep road. This alteration of pathways is particularly important in a society in which transhumance forms an important part of the traditional economy. Routes up-glacier and across-glacier have been affected both by slope failure and by glacier behaviour. In 1986, for example, a relatively small landslide damaged the upper part of a path down the Hopar face and significantly increased the hazard to humans and animals using the path. Similarly, it was not unusual to observe the demise of sheep and goats which had slipped into crevasses when ice-surface conditions obstructed the route across Bualtar Glacier (Fig. 6). Rapid ice acceleration during 1987 crevassed the

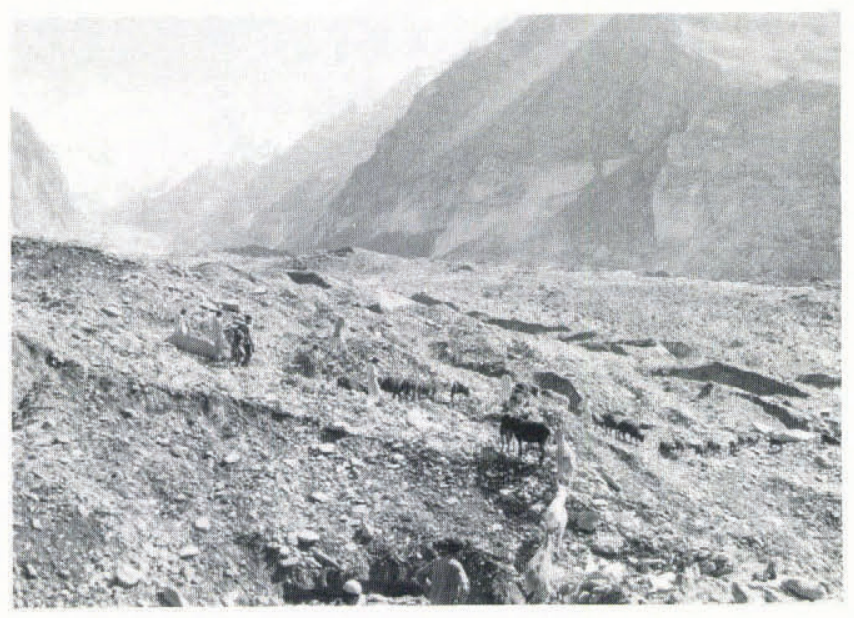

Fig. 6. Animals being herded across Bualtar Glacier to Hopar, from areas of high pasture. Daily fluctuations in ice-surface condition and slope form pose a severe hazard both to humans and to animals. glacier surface to such an extent that neither humans nor animals could traverse the glacier for a number of months. A detour not only entailed considerably greater travelling time to pasture areas but also strained relationships with communities at lower elevations, as animals had to be herded through these villages in order to reach the high pastures. Additionally, crevassing effectively cut villages off from important sources of wood fuel and increased the pressure on exisiting reserves within the valley.

\section{DISCUSSION AND CONCLUSION}

The hazard condition at Hopar can be described as chronic rather than catastrophic. It is a continuing and uncontrollable natural process and villagers have developed a coping mechanism in response to this hazard. Damage resulting from this chronic problem is as destructive as that created by more catastrophic events, and may cumulatively be greater over a long period of time. Similarly, social and economic changes resulting from chronic hazard can have a greater impact than those resulting from a sudden event. The landslide problem in Hopar is compounded by a changing local social structure and by the increasing prevalence of a monetary economy. The hazard adds to and intensifies the burden on those villagers whose work maintains a subsistence economy, that is primarily women and elderly menfolk. One labour-intensive solution to the landslides, that of occupying virgin land, is precluded thus far by a perceived labour shortage, the subsistence base of the economy being subservient to acquiring cash inflow and to attempts to benefit from new development. Absence of remuneration acts as a deterrent to opening up available new land; subsidized grain supplies further aggravate this deterrent; because it is generally perceived as temporarily advantageous to accept the economic benefit of subsidization rather than to exert the effort required to open, irrigate, and produce a crop on new land. It is in relation to such considerations that village leaders rate the severity and cost of the landslide hazard. They have expressed the thought that the villages might benefit more if the landslides were sudden and calamitous. It is also in relation to daily living conditions that glacier behaviour is perceived to be important by valley residents who must alter their daily routines and cultural practices, in varying degrees, to accommodate fluctuations in glacier flow and the resulting changes in slope form and ice-surface topography.

\section{ACKNOWLEDGEMENTS}

This work has been supported by a Short-term Research Grant from Wilfrid Laurier University (WLU), Waterloo, Ontario, and by the Snow and Ice Hydrology Project, a joint venture by WLU, the International Development Research Centre (Canada), and the Water and Power Development Authority (Pakistan). Thanks are due to Dr K. Hewitt, Dr G. Young, and Dr J. Gardner for their valuable help and discussion, and to an anonymous reviewer. While in the field, the author received invaluable aid from S. Ahmed of Nagyr and from numerous residents of the Hopar valley.

\section{REFERENCES}

Eisbacher, G.H. and J.J. Clague. 1984. Destructive mass movements in high mountains: hazard and management. Geol. Surv. Can. Pap. 84-16.

Hewitt, K. 1988. Catastrophic landslide deposits in the Karakoram Himalaya. Science, 242, 64-66.

Jones, F.O. and others. 1961. Landslides along the Columbia River valley, north-eastern Washington. U.S. Geol. Surv. Prof. Pap. 367.

Varnes, D.J. 1978. Slope movements and types and processes. In Schuster, R.L. and R.J. Krizek, eds. Landslides: analysis and control. Washington, DC, National Academy of Science. Transportation Research Board, 11-33. (Special Report 176.) 